\title{
Karolina Gadzała
}

WAGO ELWAG Sp. z o.o.

e mail: gadzala.karolina@gmail.com

\section{Tomasz Lesiów}

Uniwersytet Ekonomiczny we Wrocławiu e-mail: tomasz.lesiow@ue.wroc.pl

ORCID: 0000-0002-1284-5874

\section{WYBRANE AKTUALNE TRENDY ŻYWIENIOWE. PRACA PRZEGLĄDOWA}

\section{SELECTED CURRENT NUTRITIONAL TRENDS. REVIEW WORK}

DOI: 10.15611/nit.2019.2.01

JEL Classification: Q19

Streszczenie: Wiedza o trendach w żywieniu jest aspektem ważnym w kontekście zdrowia oraz jakości życia zarówno dla konsumentów, jak i przedsiębiorstw, ponieważ muszą one odpowiadać na wyzwania konsumentów, wyprzedzać je, by zdobyć nowych klientów, a co za tym idzie - zwiększać zyski. Celem artykułu jest scharakteryzowanie wybranych aktualnych trendów żywieniowych i dietetycznych. Wyróżnia się następujące przesłanki podążania za trendami żywieniowymi: zdrowotne, kulturowe, religijne, etyczne, ekologiczne, psychologiczne, finansowe i związane z globalizacją. Wskazano na istotę, korzyści i ograniczenia stosowania diet wegetariańskiej, wegańskiej i fleksitariańskiej, eliminacyjnej (diet bezglutenowej i bez laktozy), o niskim indeksie glikemicznym, diety w insulinooporności, diety wpływającej na zdrowie psychiczne (żywności komfortowej, oddziałującej pozytywnie na nastrój i emocje i uważne jedzenie), a także diet, które wiążą się z elimanacją marnotrawstwa jedzenia (zero odpadów, mniej odpadów, ekologiczna konsumpcja). Stosowanie każdej z nich i ich odpowiednie zbilansowanie powinno być poparte zaleceniami dietetyka i lekarza.

Słowa kluczowe: trendy żywieniowe, trendy dietetyczne, globalne trendy, wegetarianizm, diety eliminacyjne, diety poprawiające samopoczucie, diety eliminujące marnotrawstwo.

\begin{abstract}
Consumers' knowledge of the trends in nutrition is an aspect important not only in terms of their health and quality of life but also for food industry companies. They must respond to consumers' challenges and even stay ahead of them to win a crowd of new customers, thus increasing profits. The study aim is to characterize selected current nutritional and dietary trends. The following reasons for consumers to follow dietary trends are health, cultural, religious, ethical, ecological, psychological, financial, and connected with globalization. The essence, benefits, and limitations resulting from the use of different diets: vegetarian, vegan, and flexitarian diets, elimination diets (gluten-free diet and lactose-free diet), low-
\end{abstract}


glycemic index diet, diet in insulin resistance, diets affecting mental health (comfort food, mood food, and mindful eating), and diets that include the elimination of food waste (no waste, less waste, freeganizm) were indicated. A dietician and doctor's recommendations should support the sensible use of any diet and its proper balance.

Keywords: nutritional trends, dietary trends, global trends, vegetarianism, elimination diets, wellbeing diets, waste-free diets.

\section{Wstęp}

W XXI wieku powiedzenie „czas to pieniądz” nabrało szczególnego znaczenia - na spożywanie posiłku jest go o wiele mniej niż kiedyś. W efekcie na całym świecie powstało wiele miejsc, w których posiłek można spożyć szybko i tanio. Popularność uzyskały również dania o wysokim stopniu przetworzenia, łatwe do przygotowania w krótkim czasie. Taki sposób odżywiania, a także coraz częstsze sytuacje stresogenne czy zmiana stylu życia na mniej aktywny skutkują m.in. zwiększeniem otyłości (Gajda-Konopka i Lesiów, 2017). W dobie powszechności Internetu konsumenci zaczęli zauważać, że ich styl odżywania oraz jakość posiłków stają się coraz gorsze. Zaobserwowano rosnącą aktywność prozdrowotną konsumentów, która jest rozpatrywana przez pryzmat zmian w żywieniu, formach gospodarowania czasem wolnym czy też organizacji stosunków międzyludzkich w trakcie i po pracy (Hanus, 2017). Konsumenci zaczęli uzyskiwać informacje o coraz nowszych trendach w żywieniu, które w założeniu miałyby im pomóc w poprawie sposobu odżywiania, a co za tym idzie - również w polepszeniu jakości życia (Wansink, 2010). Problem stanowi jednak selekcja tak ogromnej ilości informacji, ponieważ duża ich liczba może być nieprawdziwa. Na nieprawdziwe informacje są w szczególności narażone osoby młode, które dopiero kształtują swoje nawyki żywieniowe, a które mogą nie być w stanie zweryfikować poprawności uzyskanych wiadomości na temat aktualnie występujących globalnych trendów żywieniowych, niekoniecznie pozytywnie wpływających na zdrowie człowieka.

Warte omówienia są także przesłanki, jakimi kierują się konsumenci w podążaniu za danymi trendami w żywieniu, ponieważ może to dostarczyć wielu informacji o nich samych - o tym, czy robią to ze względu na własne zdrowie, chwilowo panującą modę, na ekologię czy dlatego, że osoby z ich otoczenia stosują daną dietę. Również przedsiębiorstwa z branży żywnościowej muszą nadążać za nowymi trendami w żywieniu, aby wyjść konsumentom naprzeciw i spełnić ich oczekiwania, a także by je wyprzedzić i wykreować nowe trendy, za którymi podąży rzesza nowych konsumentów umożliwiających przedsiębiorstwom zwiększyć zyski (Nosarzewski, 2020).

Celem artykułu jest scharakteryzowanie wybranych aktualnych trendów żywieniowych i dietetycznych. 


\section{Trendy żywieniowe/dietetyczne}

Trend jest definiowany przez Stownik języka polskiego $P W N$ jako ,istniejący w danym momencie kierunek rozwoju w jakiejś dziedzinie" (Drabik i Sobol, 2019). Według słownika Cambrigde English dictionary dictionary (2020) jest to „ogólny rozwój lub zmiana sytuacji lub sposobu, w jaki ludzie się zachowują".

Pojęcie to pojawia się wszędzie tam, gdzie występuje zachowanie grupowe. Podążanie za trendami stanowi naturalne ludzkie zachowanie, podobnie jak ich ignorowanie, jednak należy pamiętać, że analiza trendów dostarcza wielu informacji dotyczących ludzkich zachowań, postępowań i wyborów (Kucner, Sierocki i Wasyluk, 2018). Termin ten jest powszechnie używany w wielu dziedzinach życia gospodarczego, np. w handlu, przemyśle czy nauce i sztuce.

\subsection{Trend żywieniowy a moda żywieniowa}

Termin „trend żywieniowy” znalazł również zastosowanie w naukach o żywności i żywieniu człowieka. W tym kontekście opisywany jest jako „dominujący nawyk konsumpcji lub tendencja do spożywania określonego składnika, potrawy lub stylu przygotowywania" (Albala, 2015).

Ważną kwestią jest odróżnienie trendu żywieniowego od mody żywieniowej. Bizzozero (2019) w swoim artykule przytoczyła słowa Dornblaser, według której trend żywieniowy można określić jako taki, który wykazuje powolny, stały wzrost w czasie wraz ze stopniowym spadkiem pojawiających się w nim nowych produktów. Dany nawyk konsumpcji ma zastosowanie do różnych kategorii artykułów żywnościowych, jest wszechstronny oraz łatwy do przyjęcia przez konsumentów, restauracje i sklepy. Z kolei moda w żywieniu pojawia się szybko i tak samo szybko rośnie i znika. Występuje ona w ograniczonej liczbie kategorii produktów żywnościowych, a także jest trudna do przyjęcia przez konsumentów, restauracje czy sklepy detaliczne. Jest definiowana jako trwająca stosunkowo krótko.

W literaturze brakuje jasno sformułowanego pojęcia trendu dietetycznego, jednakże można go utożsamiać z terminem trendu żywieniowego, ponieważ również jest to nawyk konsumenta do spożywania danego rodzaju artykułów żywnościowych, jednak jest to przeważnie związane z celem, takim jak na przykład utrzymanie lub utrata masy ciała lub kwestie zdrowotne (niemożność spożywania danego typu żywności z powodu nietolerancji lub alergii pokarmowej). $Z$ kolei pojęcie trendu żywieniowego jest pojęciem szerszym, obejmuje bowiem również tendencje w żywieniu konsumentów, które są związane m.in. z aspektami ekologicznymi, psychologicznymi, religijnymi. 


\subsection{Przesłanki podążania przez konsumentów za trendami w żywieniu}

Podążanie konsumentów za trendami w żywieniu należy rozpatrywać w kontekście badań nad socjologią żywności i jedzenia, która rozwinęła się z końcem XX wieku, gdy zaczęto przywiązywać wagę do zachowań żywieniowych ludzi. Badania nad związkiem jedzenia, żywności i kultury rozwinęli m.in. Mennell i inni (Mennell, Murcott i van Otterloo, 1992) oraz Poulain (2002), w Polsce zaś - Domański i inni (Domański, Karpiński, Przybysz i Straczuk, 2015). Wszyscy autorzy zwracają uwagę na to, jak wiele aspektów oddziałuje na zachowania i nawyki żywieniowe ludzi. Kwestie te mają także odzwierciedlenie w podazżaniu przez jednostki czy grupy społeczne za globalnymi trendami żywieniowymi (Bylok, 2018).

Rozważając motywy konsumentów w podążaniu za danymi trendami żywieniowymi/dietetycznymi, można wymienić wiele wpływających na nie aspektów życia codziennego. Mowa tu m.in. o aspektach zdrowotnych, etycznych, religijnych, ekologicznych (dbania o środowisko naturalne), psychologicznych, kulturowych (rodzinnych) czy finansowych. Istotną rolę w kształtowaniu zachowań konsumentów wobec trendów w żywieniu odgrywają również środki masowego przekazu (mass media, czyli Internet, telewizja, radio, prasa) oraz zjawisko globalizacji.

Najważniejszym czynnikiem, który powoduje podążanie konsumentów za trendami w żywieniu, są kwestie zdrowotne. Najczęściej są one związane z występującymi alergiami i nietolerancjami pokarmowymi. Do elimanacji z diety danego produktu żywnościowego dochodzi nie tylko wtedy, gdy zostaną one zdiagnozowane, ale i wówczas, gdy u konsumenta występują pewne obawy żywieniowe, np. przeświadczenie lub niepewność czy dany składnik diety nie działa negatywnie na organizm. Wielu konsumentów decyduje się też na wykluczenie z jadłospisu mięsa, co wiąże się m.in. z ich niepewnością co do oddziaływania sposobu produkcji na jakość mięsa. Istotną rolę w podążaniu za trendami żywieniowymi w aspekcie zdrowia odgrywa także tendencja do zarządzania zdrowiem przez konsumentów. Kryje się za nią większe zainteresowanie własnym stanem zdrowia, czyli takie działania, jak samoobserwacja, regularne wizyty lekarskie, zdrowe odżywianie oraz balans pomiędzy ciałem a umysłem, czyli odpowiedni odpoczynek, sen, aktywność fizyczna (Hanus, 2017).

Wśród czynników kulturowych tendencją, która kształtuje współczesne wzory żywienia, jest coraz mniejszy wpływ tradycji na życie codzienne. Zachowania indywidualnych osób są coraz słabiej kształtowane przez normy obowiązujące w społeczeństwie, co można zauważyć m.in. w większej dowolności sposobu jedzenia. Ze względu na coraz szybsze tempo życia oraz stres ludzie spożywają posiłki częściej w samotności lub w zakładach żywienia zbiorowego aniżeli w gronie rodzinnym. Socjologowie zajmujący się związkami tradycji i jedzenia posługują się w tym przypadku pojęciem gastroanomii, którym określają zjawisko zanikania rytualnych posiłków spożywanych jako wspólnota (Maj, 2018). 
$\mathrm{Na}$ życie człowieka silnie oddziałują także wyznawana religia czy kierowanie się etyką, czyli zbiorem zasad moralnych. Wiąże się to także z kwestią odżywiania, a co za tym idzie - wyborem trendu żywieniowego, za którym chce się podążać, a który jest dozwolony w danej religii. Składnikiem diety najczęściej eliminowanym przez religie jest mięso (Jedlecka, 2016).

Przykładem trendu, którego zasady pokrywają się z zasadami różnych religii, są wegetarianizm, weganizm oraz fleksitarianizm. Osoby niekoniecznie utożsamiające się z zasadami danej religii, ale wyznające pewien zbiór zasad moralnych kierują się nimi także w wyborze diety czy trendu w żywieniu. Jest to związane $\mathrm{z}$ zasadą poszanowania życia każdej żyjącej istoty, z niezgodą na cierpienie zwierząt w hodowlach, ale także z faktem, iż już obecnie hodowle te są mocno eksploatowane, a szacuje się, iż aby wyżywić w przyszłości rosnącą światową populację, konieczne będzie m.in. wynalezienie alternatyw dla mięsa hodowlanego, czyli wprowadzenie na rynek np. mięsa wyprodukowanego $\mathrm{z}$ innych surowców w warunkach laboratoryjnych (Dejnaka, 2019; Hatalska i Trapp, 2017; Jankojć, Lesiów i Biazik, 2016a, 2016b).

Kwestie etyczne są często powiązane $\mathrm{z}$ aspektami ekologicznymi. Mowa tu ogólnie o trosce o planetę i dbaniu o środowisko naturalne, w którym żyjemy. Zmienia się motywacja ludzi z egoistycznej, mającej na celu wyłącznie zaspokojenie własnych potrzeb, na społeczna, czyli podyktowaną społecznymi przesłankami. Uświadomienie sobie problemów środowiska naturalnego zmotywowało ludzi do zmian w stylu życia oraz sposobie odżywiania, co z kolei przyczyniło się do powstania wielu trendów żywieniowych, np. less waste, zero waste czy freeganizmu, a wielu ludzi skłoniło do podporządkowania się tym zasadom (Grzybowska-Brzezińska, 2011; Żakowska-Biemans, 2011). Innym czynnikiem wiążącym się z aspektami ekologicznymi są zjawiska dekonsumpcji oraz zrównoważonej konsumpcji. Wraz ze wzrostem zamożności społeczeństwa i pojawieniem się na rynku wielu produktów, które zaspokajają różne potrzeby, ludzie zaczęli kupować dużo produktów, urządzeń, ubrań, zabawek, które w perspektywie czasu okazywały się niepotrzebne. Świadomość ekologiczna natchnęła konsumentów do przemyślenia kwestii nadmiernej konsumpcji, co spowodowało pojawienie się zjawiska dekonsumpcji, czyli świadomego ograniczenia wydatków przeznaczanych na konsumpcję jednostki. Idea zrównoważonej konsumpcji różni się od zjawiska dekonsumpcji tym, iż ta druga jest głównie związana z kwestiami ekonomicznymi, natomiast pierwsza - z pozyskiwaniem dóbr w umiarze, takich, które nie mają negatywnego wpływu na środowisko naturalne (Radziszewska, 2017). Z tymi zasadami utożsamiają się zarówno freeganizm, jak i less waste oraz zero waste.

Równie istotnym czynnikiem mającym wpływ na kierowanie się w odżywianiu trendem żywieniowym/dietetycznym są aspekty psychologiczne. Wykazana została zależność między żywnością a psychiką człowieka. Jest dostępnych wiele badań, dowodzących, iż spożywanie danego rodzaju posiłków może pozytywnie wpłynąć na samopoczucie i poprawić nastrój. Dla wielu osób jedzenie jest sposobem na poradzenie sobie z negatywnymi emocjami, bólem czy problemami (Bylok, 2018). 
Analizując przesłanki podążania ludzi za trendami w żywieniu, konieczne jest zwrócenie uwagi na aspekt finansowy. Wiele osób może zdecydować się na zmianę swoich nawyków żywieniowych ze względu na oszczędności. Mowa tu np. o takich trendach, jak less waste czy zero waste, dzięki którym można nie tylko zadbać o los planety, ale także dokonywać świadomych zakupów, co może się wiązać z zaoszczędzeniem pieniędzy (freeganizm) (Jaworski i Fabisiak, 2017).

Globalizacja, utożsamiana ze zjawiskiem zwiększonego przepływu informacji, kapitału, towarów oraz usług, przyczyniła się do tego, że ludzie uzyskali dostęp do żywności innej niż lokalna, ponieważ pojawiła się możliwość jej transportowania w krótkim czasie i na duże odległości. Dzięki globalizacji rozwinęły się także środki masowego przekazu, które wywierają duży wpływ na formowanie się przekonań konsumentów dotyczących jedzenia, a także na tworzenie i propagowanie nowych trendów. Jednym z przykładów takiej mody, która stała się trendem jest dieta eliminująca gluten (Maj, 2018).

\subsection{Trendy żywieniowe/dietetyczne a zasady zdrowego odżywiania}

Rosnąca świadomość konsumentów dotycząca żywności i żywienia, globalizacja informacji, powszechny dostęp do Internetu wpływają na pojawianie się coraz nowszych trendów w żywieniu. Wiele osób podąża za nimi, nie sprawdzając ich zasadności i bezpieczeństwa dla zdrowia, co może wywoływać wiele negatywnych skutków dla organizmu. Dlatego ważna jest weryfikacja informacji o danym trendzie dietetycznym, umożliwiająca zniwelowanie zagrożenia dla zdrowia. Co więcej, przy doborze diety należy pamiętać o odpowiednim zbilansowaniu składników odżywczych.

Według Narodowego Centrum Edukacji Żywieniowej Instytutu Żywności i Żywienia (NCEŻ IŻŻ) wiedzę dotyczącą trendów w żywieniu powinno się czerpać z takich źródeł, jak: badania naukowe (najbardziej wartościowe są przeglądy statystyczne, a także metaanalizy badań randomizowanych), czasopisma naukowe (polskie i zagraniczne, ponieważ podlegają recenzji naukowej), książki i podręczniki (zaleca się sprawdzenie, czy dana książka zawiera bibliografię, a także dorobek naukowy, doświadczenie i wykształcenie autora publikacji), artykuły bazujące na badaniach naukowych (artykuły popularnonaukowe - zwraca się uwagę na weryfikację autora i wykorzystanej przez niego bibliografii) oraz eksperci w dziedzinie żywności i żywienia - wyróżnia się wśród nich naukowców, wykwalifikowane osoby z kierunkowym wykształceniem dotyczącym dietetyki, z doświadczeniem w danej dziedzinie, którzy systematycznie uzupełniają swoją wiedzę (Instytut Żywności i Żywienia, 2017).

Stosując dietę wegetariańską bądź rozważając jej wprowadzenie, należy pamiętać, iż odpowiednio zbilansowana powinna zapewnić wszystkie potrzebne organizmowi składniki odżywcze (Pyrzyńska, 2013). Dieta jarska jest zwykle bogata w węglowodany złożone, błonnik, karotenoidy, kwasy thuszczowe omega 6 , witaminy 
C i E, kwas foliowy oraz magnez. Charakteryzuje się ona także stosunkowo niższą zawartością białka, witaminy $\mathrm{B}_{12}$ (kobalaminy), cynku, tłuszczów nasyconych, wapnia i żelaza oraz długołańcuchowych kwasów tłuszczowych omega 3 (Stolińska-Fiedorowicz, 2017).

Biorąc pod uwagę aktualny stan wiedzy żywieniowej, nie rekomenduje się stosowania radykalnych form wegetarianizmu (frutarianizmu - spożywania wyłącznie owoców, witarianizmu - spożywania wyłącznie surowych warzyw i owoców, weganizmu - spożywania wyłącznie wszelkiego rodzaju surowych lub przetworzonych pokarmów roślinnych) przez pewne grupy osób - dzieci, młodzież, kobiety ciężarne i karmiące oraz osoby ciężko pracujące fizycznie, ponieważ nie są one pełnowartościowe pod względem wartości odżywczej i mogą stanowić zagrożenie dla zdrowia (Gertig i Przysławski, 2006; Stanowisko Komitetu Nauki o Żywieniu Człowieka PAN, 2019).

Według Desmond i Sobieckiego (2019) wymagana jest suplementacja witaminy $\mathrm{B}_{12} \mathrm{w}$ dietach wegetariańskich i wegańskich. Autorzy zwracają uwagę, że w kiszonkach, a także wodorostach i drożdżach występują jedynie nieaktywne formy witaminy $\mathrm{B}_{12}$, a synteza tej witaminy przez bakterie jelitowe ma miejsce w częściach jelit dalszych niż te, w których możliwe jest jej wchłanianie. Szczególnie istotna jest suplementacja witaminy $\mathrm{B}_{12}$ u wegetarianek $\mathrm{w}$ wieku rozrodczym, w ciąży lub karmiących piersią i u dzieci (Desmond i Sobiecki, 2019). Niedobór witaminy $B_{12}$ jest przyczyną specyficznego rodzaju niedokrwistości, a także może prowadzić do poważnych problemów neurologicznych, w tym do nieodwracalnego uszkodzenia układu nerwowego. Może się też przyczyniać do wzrostu we krwi stężenia homocysteiny, której nadmiar jest szkodliwy dla neuronów i naczyń krwionośnych.

W przypadku wegan konieczne jest spożycie zamienników produktów mlecznych wzbogacanych wapniem (np. napojów sojowych, migdałowych lub suplementów wapnia), których producenci starają się uzyskać takie stężenia wapnia, jakie cechuje mleko krowie. Dla wegetarian i wegan nie ma oficjalnych wytycznych dotyczących suplementacji kwasów omega 3, zasadne pozostaje stosowanie wyciagów $\mathrm{z}$ alg na poziomie około $250 \mathrm{mg}$ DHA i EPA dziennie, ponieważ jest ono równoważne z zaleceniem spożywania ryb dwa razy w tygodniu dla reszty populacji. Konieczność suplementacji dotyczy także witaminy D, która w produktach roślinnych praktycznie nie występuje. Diety roślinne są też z reguły znacznie uboższe w wapń. Niedobory wapnia i witaminy D wpływają niekorzystnie na układ kostny. U ludzi dorosłych są na ogół przyczyną osteomalacji, u osób starszych - osteoporozy, zaś u dzieci - krzywicy. Skutkami niedostatecznego pokrycia zapotrzebowania na mikroelementy (żelazo, cynk i selen) u wegan, frutarian i witarian są m.in. niedokrwistość, obniżenie odporności, dysfunkcje tarczycy, zaburzenia sensoryczne, zmniejszenie płodności i poronienia (Stanowisko Komitetu Nauki o Żywieniu Człowieka PAN..., 2019).

W pracy (Derbyshire, 2017) stwierdzono, że diety fleksitariańska (bez lub z uwzględnieniem niewielkich ilości mięsa drobiowego bądź innych rodzajów mię- 
sa) i semiwegetariańska (bez lub z uwzględnieniem niewielkich ilości mięsa drobiowego) mogą mieć korzyści zdrowotne, przy czym najbardziej wydają się mieć związek z utratą masy ciała i metabolicznymi korzyściami zdrowotnymi, włączając $\mathrm{w}$ to zmniejszone ryzyko cukrzycy i nadciśnienia tętniczego. Odpowiednio zbilansowana dieta fleksitariańska nie powinna negatywnie wpływać na zdrowie i życie.

Wdrożenie diety eliminacyjnej jest konieczne z powodu choroby, alergii lub nietolerancji na pewien składnik występujący w diecie. Najczęstszymi dietami tego typu są dieta bezglutenowa oraz bez laktozy. Odpowiednie ułożenie diety, która pozwoli na zastąpienie składników odżywczych występujących w posiłkach zawierających również substancję wyrządzającą szkody u osób cierpiących na daną chorobę, nietolerancję lub alergię, pozwala na zachowanie zdrowia, dzięki czemu stosowanie diety jest całkowicie zdrowe. Jednak w dostępnych obecnie wynikach badań naukowych nie podano dowodów na korzyści wdrożenia tego typu diet u osób niemających tych dolegliwości. Nieumiejętne, bezzasadne wprowadzenie diety bezglutenowej u osoby zdrowej może być przyczyną niekorzystnych zmian w organizmie następujących na skutek niedostatecznej podaży energii, składników mineralnych, witamin oraz makroskładników (Dittfeld, Gwizdek, Parol i Michalski, 2018; Michałowska, Pastusiak i Bogdański, 2017). Nie ma dowodów naukowych potwierdzających korzyści ze stosowania diety wykluczającej laktozę u osoby zdrowej, niemającej dolegliwości związanych z nietolerancją laktozy czy alergią na mleko krowie (podobnie jak w przypadku diety bezglutenowej u osób niemających alergii na gluten). Wręcz przeciwnie - według naukowców eliminacja laktozy u osoby zdrowej prowadzi do rozleniwienia układu enzymatycznego człowieka, ponieważ enzym odpowiedzialny za rozkład cukru mlecznego, czyli laktozy, przestaje być aktywny, gdy nie ma czego rozkładać (Wieczorkiewicz, 2018).

Dieta o niskim indeksie glikemicznym (IG) jest skierowana do osób, u których występują zaburzenia gospodarki węglowodanowej. Celem diety jest zmniejszenie stężenia glukozy we krwi i poprawa metabolizmu. Zaleca się ją pacjentom cierpiącym na insulinooporność oraz cukrzycę typu 1 i typu 2, a także przyszłym mamom, u których cukrzyca wystapi w okresie ciąży. Dieta ta jest oparta na produktach ubogich w weglowodany łatwo przyswajalne, czyli cukry (Bonavita.pl, b.d.).

$\mathrm{Z}$ kolei dieta o wysokim indeksie glikemicznym jest szkodliwa dla zdrowia, przyczynia się bowiem do wystąpienia niebezpiecznych schorzeń. Wiele badań epidemiologicznych wykazało, że dieta o wysokim IG prowadzi do insulinooporności komórek, która jest bezpośrednią przyczyną cukrzycy typu 2. Wysoki IG diety jest również czynnikiem rozwoju chorób układu krążenia, w tym choroby niedokrwiennej serca oraz miażdżycy. Wysoki indeks diety przyczynia się także do wzrostu stężenia we krwi białka C-reaktywnego (CRP), które wywołuje stany zapalne w organizmie. Wysoki indeks glikemiczny produktów zwiększa też ryzyko występowania schorzeń, których podstawą jest wytwarzanie wolnych rodników uszkadzających tkanki (ABCzdrowie, b.d.). 
Podstawową zasadą diety w insulinooporności jest eliminacja cukru oraz żywności go zawierającej (Różańska, 2020). Dieta opiera się na produktach o niskim indeksie glikemicznym, tj. takich, po których zjedzeniu nie wzrasta poziom cukru we krwi, dzięki czemu nie dochodzi do skoku insuliny. Zmiany w diecie - ograniczenie niezdrowych źródeł węglowodanów prostych, a więc cukrów (słodycze, słodzone napoje), wzbogacenie diety o produkty bogate w błonnik, spożywanie kilku mniejszych posiłków w ciagu dnia - pozwala na utrzymanie stałego poziomu cukru we krwi. Wskazane jest zwiększenie aktywności fizycznej, dzięki czemu komórki mięśniowe stają się bardziej wrażliwe na działanie insuliny (Adamiak, 2020).

W przypadku zdiagnozowania insulinooporności odpowiedzialnej za ciagle zmęczenie, obniżenie nastroju, rozdrażnienie, bóle głowy, uczucie zimna, częstą ochotę na słodycze, zmiany na skórze, problemy z pamięcią, koncentracją i nadwagą koniecznością staje się zmiana stylu życia i diety. $\mathrm{Z}$ pomocą dietetyka powinno się ułożyć zbilansowaną i zindywidualizowaną dietę (Adamiak, 2020; Różańska, 2020).

Trendami żywieniowymi związanymi z ludzką psychiką są comfort food, mindful eating oraz mood food. Osoby za nimi podążające starają się spożywać produkty żywnościowe i posiłki, które mogą poprawić ich nastrój oraz samopoczucie psychiczne. Jednak analiza przykładów takich produktów żywnościowych nakazuje zachowanie rozwagi, ponieważ często jako przykłady produktów poprawiających nastrój podaje się słodycze, słone przekąski, posiłki o wysokiej zawartości tłuszczu i węglowodanów czy przygotowane przez obróbkę termiczną w głębokim tłuszczu. Nasuwa się więc wniosek, że pomimo pozytywnego wpływu tego typu produktów na samopoczucie psychiczne ludzi należy ograniczać spożycie tego rodzaju produktów, ponieważ dzięki temu możliwe jest zachowanie dobrej jakości zdrowia (Maj, 2018).

Biorąc pod uwagę ostatnią kategorię trendów żywieniowych/dietetycznych, które obejmują nie tylko odżywianie się, ale również inne aspekty życia, czyli freeganizm, less waste oraz zero waste, należy zauważyć, że nie istnieją określone typy żywności spożywane przez osoby podążające za tymi trendami. Dzieje się tak, ponieważ osoby te w wyborze pożywienia kierują się względami m.in. ekonomicznymi czy ekologicznymi i nie mają one ściśle ułożonej listy produktów dozwolonych do spożycia. Nie można zatem stwierdzić związku tych trendów ze zdrowym odżywianiem, gdyż jest to kwestia indywidualna osób żyjących zgodnie z wybranym trendem, będącym jednocześnie stylem życia, którego jedną z zasad jest eliminacja marnotrawstwa żywności.

\section{Globalne trendy w żywieniu konsumentów}

Obecnie na świecie panuje wiele trendów żywieniowych i dietetycznych, jednak najbardziej znane są: wegetarianizm, weganizm, fleksitarianizm, dieta wykluczająca laktozę, dieta wykluczająca gluten, comfort food, mood food, mindful eating, zero waste, less waste, freeganizm. 
Na potrzeby niniejszego opracowania zostały one przyporządkowane do czterech kategorii, które stanowią:

- Diety wykluczające mięso lub mięso oraz składniki pochodzenia zwierzęcego.

- Diety wykluczające gluten, laktozę. Dieta o niskim indeksie glikemicznym i dieta $\mathrm{w}$ insulinooporności.

- Żywność wpływająca na zdrowie psychiczne.

- Eliminacja marnotrawstwa jedzenia.

\subsection{Diety wykluczające mięso lub mięso oraz składniki pochodzenia zwierzęcego - wegetarianizm, weganizm oraz fleksitarianizm}

Decyzja o wyeliminowaniu z diety mięsa bądź mięsa wraz z składnikami pochodzenia zwierzęcego, takimi jak np. mleko czy sery, może być podyktowana motywami zdrowotnymi, ekonomicznymi, etycznymi, ekologicznymi, religijnymi czy filozoficznymi, lecz zawsze wiąże się z modyfikacją aktualnych przyzwyczajeń żywieniowych człowieka. Często także oznacza odrzucenie zwyczajów kultury europejskiej, w której od lat mięso jest jednym z podstawowych elementów diety (Kunachowicz, Czarnowska-Misztal i Turlejska, 2000).

Wśród najpopularniejszych trendów żywieniowych w tej kategorii wyróżniamy wegetarianizm, weganizm oraz fleksitarianizm.

Jedną z najbardziej znanych diet alternatywnych, czyli różniących się od powszechnie przyjętego sposobu żywienia, jest dieta wegetariańska, która stanowi dobrowolną rezygnację ze spożywania określonych pokarmów. Nazwa pochodzi od łacińskiego słowa vegetabilis - ,roślinny”. Jarstwo, czyli klasyczny wegetarianizm, polega na spożywaniu jedynie pokarmów pochodzenia roślinnego, czyli roślin zbożowych, okopowych, oleistych i strączkowych, a także owoców, warzyw, grzybów oraz orzechów. Dieta ta wywodzi się z Indii i terenów Bliskiego Wschodu, zazwyczaj wiąże się z unikaniem alkoholu, tytoniu, a także z kontaktem z przyrodą i dbałością o kondycję psychofizyczną (Gawęcki, 2007).

Weganizm, będący jednym z rygorystycznych rodzajów diety wegetariańskiej, polega na wyeliminowaniu z jadłospisu nie tylko mięsa, ale również nabiału, jaj oraz niekiedy miodu (Wieczorek, 2016). Weganizm wyodrębnił się z ruchu wegetariańskiego w 1944 r. Niewątpliwie powstał on wcześniej, jednak niektórzy wegetarianie nie zdawali sobie sprawy, że w istocie są weganami. W roku 1944 powstało The Vegan Society będące pierwszą na świecie wegańską organizacją (Gzyra, 2013).

Nierzadko spożywanie posiłków wegetariańskich może stanowić zbyt duże wyrzeczenie, a skomponowanie odpowiednich posiłków bez wsparcia dietetyka może być dla niektórych wręcz niewykonalne. Dlatego też popularna stała się dieta fleksitariańska, w której posiłki są w większym stopniu roślinne, a rezygnacja z mięsa nie jest całkowita. Określenie „fleksitarianizm” powstało w wyniku połączenia dwóch angielskich słów - flexible (elastyczny) oraz vegetarian (wegetariański). Na tej podstawie można stwierdzić, że fleksitarianizm to inaczej elastyczny wegetarianizm. 
Osoby będące zwolennikami tego rozwiązania twierdzą, że nie jest konieczna całkowita eliminacja mięsa $z$ diety, aby możliwe było osiagnięcie korzyści zdrowotnych płynących z wegetarianizmu. Pojęcie to ma też drugie znaczenie, według którego za fleksitarian uznaje się osoby spożywające mięso tylko okazjonalnie (np. poza domem, na przyjęciach, w domach przyjaciół lub rodziny), a stosujące w swoim domu dietę wegetariańską lub wegańską (Fleksitarianizm, b.d.).

Odpowiednio zbilansowana dieta fleksitariańska powinna dostarczać organizmowi wszystkie niezbędne składniki odżywcze. Nie nastręcza to trudności, ponieważ fleksitarianizm bierze za podstawę zasady racjonalnego żywienia, a częściowa eliminacja mięsa i jego przetworów odróżnia go od klasycznej diety (Wiśniewska, 2018).

\subsection{Diety wykluczające gluten i laktozę}

Jednym z najpopularniejszych trendów żywieniowych w ostatnich latach jest dieta bezglutenowa, będąca dietą eliminacyjną wykluczającą białka glutenu. Definicja według Kodeksu żywnościowego FAO/WHO sformułowana w 2008 r. określa gluten jako frakcję białka, która nie rozpuszcza się w wodzie i $0,5 \mathrm{M} \mathrm{NaCl}$. Białko to występuje w pszenicy, owsie, życie, jęczmieniu, a także w ich pochodnych oraz w odmianach mieszańcowych, czyli pszenżycie (Bubis i Przetaczek-Rożnowska, 2016). Żywienie polegające na całkowitej eliminacji białka glutenu $\mathrm{z}$ diety jest wskazane dla osób chorych na celiakię, czyli glutenozależną chorobę trzewną. Charakteryzuje się ona trwałą nietolerancją białek glutenu i powoduje specyficzne zmiany w błonie śluzowej jelita cienkiego, które zanikają po eliminacji glutenu z diety.

Dieta bezglutenowa stanowi dietę leczniczą nie tylko dla osób chorujących na celiakię. Coraz częściej rozpoznaje się nieceliakalną nadwrażliwość na gluten (NCG/WS), która może dotykać nawet 30\% populacji osób dorosłych. U części osób diagnozuje się również alergię na gluten (pszenicę) (Frączek, Krzywański i Krysztofiak, 2019).

U osób chorujących na celiakię nawet niewielkie ilości glutenu w pożywieniu mogą nasilać objawy chorobowe, jednocześnie wrażliwość na białko glutenu u różnych osób może być różna. Aby ułatwić tym osobom przestrzeganie diety bezglutenowej, 25 listopada 2005 r. wprowadzono dyrektywę Unii Europejskiej (2003/89/EC), w której zobowiązano producentów żywności do wpisania na etykiecie obecności potencjalnych alergenów w danym produkcie żywnościowym, w tym glutenu (Włodarek, Lange, Kozłowska i Głąbska, 2014).

Kolejną dieta, która w wyniku dużego rozpowszechnienia się stała się globalnym trendem żywieniowym, jest dieta eliminująca laktozę. Laktoza to cukier występujący w mleku ssaków, który nie znajduje się w innych produktach. Aby organizm mógł go strawić, niezbędna jest laktaza, czyli enzym wytwarzany przez rąbek szczoteczkowy w jelicie cienkim. Gdy jelito cienkie wytwarza go zbyt mało lub nie wytwarza go wcale, mówi się o występowaniu nietolerancji laktozy, zwanej hipolakta- 
zją. U osób mających nietolerancję laktozy jej rozkład na galaktozę i glukozę nie jest możliwy, zamiast tego cukier mleczny nie jest do końca strawiony - wędruje przez jelito grube i jest przyczyną występowania uciążliwych objawów, tj. gazów, bólów brzucha oraz wzdęć (Frączek i in., 2019).

Trendowi na unikanie laktozy w produktach żywnościowych uległy nie tylko osoby nietrawiące laktazy, ale także osoby zdrowe. Zachowanie to stanowi efekt oddziaływania informacji, która w ostatnich latach trafiła do szerszej świadomości społeczeństwa o tym, że osoby dorosłe trawią cukier mleczny znacznie słabiej niż niemowlęta, a u części ta zdolność całkowicie zanika. Między innymi z tego powodu wielu konsumentów zaczęło wykluczać laktozę z diety, a także uważać, że produkt bezlaktozowy jest lepszy od klasycznego (Górska, 2017). Jednak według profesora W. Bednarskiego z Wydziału Nauk o Żywności Uniwersytetu Warmińsko-Mazurskiego spożywanie produktów bez laktozy przez osoby niecierpiące na hipolaktazję lub alaktazję to z perspektywy medycznej rozleniwianie układu enzymatycznego, ponieważ bez obecności laktozy enzym laktaza przestanie być aktywny, co w kontekście ewolucyjnym może oznaczać uwstecznianie się (Wieczorkiewicz, 2018).

\section{3. Żywność wpływająca na zdrowie psychiczne - comfort food, mood food oraz mindful eating}

Jednym z popularnych na świecie trendów żywieniowych jest żywność wpływająca na zdrowie psychiczne, znana jako comfort food (żywność komfortowa). Termin comfort food odnosi się do żywności, której spożycie oferuje pewien komfort psychiczny, szczególnie emocjonalny, zapewniającej pocieszenie lub dobre samopoczucie. Często sugeruje się, że produkty żywnościowe zaliczane do kategorii żywności komfortowej charakteryzują się wysoką zawartością kalorii, czyli mają wysoką zawartość cukru i/lub węglowodanów i są one najczęściej związane z dzieciństwem $\mathrm{i} /$ lub gotowaniem w domu. Są one często przygotowywane w prosto lub tradycyjnie i mogą mieć nostalgiczny lub sentymentalny urok, przypominając dom, rodzinę czy przyjaciół. Typ posiłku wpisującego się w trend comfort food będzie się różnił w zależności od m.in. wieku osoby go spożywającej, kraju pochodzenia, miejsca zamieszkania, a co za tym idzie tradycji czy rodzaju kuchni. Wpływ na postrzeganie tego typu żywności może mieć również płeć, czego dowodzić mogą m.in. wyniki badań przeprowadzonych przez Wansinka i Sangerman (2000). W przeprowadzonej przez nich ankiecie wzięło udział ponad 1000 respondentów. Wskazanymi przez kobiety trzema produktami, które pełnią funkcję żywności komfortowej, były lody (77\% odpowiedzi), czekolada (69\%) oraz ciastka (66\%). Mężczyźni natomiast wskazali na lody (77\% odpowiedzi), zupę (73\%) oraz pizzę/makaron (72\%). Z wyjątkiem lodów mężczyźni ogólnie twierdzili, że większy komfort psychiczny zapewniają im potrawy gorące, będące głównymi posiłkami, kobiety z kolei wolały słodkie przekąski.

Innym przykładem trendu żywieniowego, który także jest związany z żywnością poprawiającą nastrój, a który w ostatnim czasie stał się aktualny na całym świecie, 
jest mood food, czyli jedzenie wpływające pozytywnie na nastrój i emocje człowieka. W comfort food posiłek czy artykuł żywnościowy jest indywidualnie uznawany przez człowieka za żywność komfortową, zatem wybór produktu jest subiektywny. Tymczasem kwestia przykładów żywności, którą można uznać za wpływającą pozytywnie na zdrowie psychiczne każdego człowieka, powinna być konsultowana z dietetykami. Przykładów posiłków czy artykułów żywnościowych, które są uważane za wartościowe i wpisują się w trend mood food jest wiele, a najbardziej znane są między innymi: łosoś (zawierający białko, witaminę D, potas, kwasy omega 3 i witaminy z grupy B, a także tryptofan, czyli aminokwas związany z konwersją serotoniny w mózgu, która wiąże się z regulacją nastroju), szpinak (będący źródłem potasu, żelaza, wapnia i kwasów omega 3), jagody (źródło witaminy C, a także potasu, przeciwutleniaczy, błonnika i enzymów trawiennych) (Barton, 2018).

Jednym z najnowszych trendów żywieniowych w ostatniej dekadzie jest mindful eating (uważne/świadome jedzenie), nazywane inaczej filozofią świadomego jedzenia. Mindful eating opiera się na metodzie zarządzania emocjami znanej jako mindfulness (uważność), będącej jedną z technik medytacji. Zakłada ona, że człowiek powinien być w pełni świadomy czynności, którą w danej chwili wykonuje, i całkowicie się na niej skupiać, by wykluczyć automatyczne wykonywanie rutynowych czynności w życiu (Bartholomew i Pearson, 2015). Mindful eating jest zdefiniowane jako połączenie między ciałem a umysłem, dzięki któremu jesteśmy świadomi tego, co jemy i jak się czujemy (Hirschmann i Zafiropoulos, 2012). Uważne jedzenie wiąże się z dokonywaniem świadomych wyborów żywieniowych oraz zwiększa świadomość przydatnych wskazówek związanych z przyjmowaniem pokarmu. Mindful eating umożliwia oddzielenie jedzenia od emocji, oznacza więc wsłuchiwanie się w swój organizm i jedzenie tylko wtedy, kiedy naprawdę jesteśmy głodni (Mindfull. com, b.d.).

Świadome jedzenie można zdefiniować jako wybieranie żywności zdrowej, która jest pożywna i której spożywanie sprawia człowiekowi przyjemność, a także korzystanie ze wszystkich zmysłów podczas jedzenia w taki sposób, by nie myśleć o niczym innym. Propagatorzy tego trendu będącego również stylem życia zwracają uwagę na to, jak istotną rolę odgrywa odpowiednio wolne tempo jedzenia, ponieważ często pojawiają się sytuacje, gdy nadmiar obowiązków powoduje pośpiech przy spożywaniu posiłków, co może wpływać na problemy z otyłością czy problemy natury psychicznej (Lofgren, 2015).

\subsection{Eliminacja marnotrawstwa jedzenia - zero waste, less waste, freeganizm}

Zyskującą w ostatnim czasie popularność praktyką dotyczącą ekologii jest poszanowanie środowiska przez redukcję odpadów, która jest związana z rozsądną konsumpcją, tak aby przyszłe pokolenia również mogły korzystać z zasobów naturalnych $\mathrm{w}$ takim samym w stopniu, w jakim ludzie mają do nich dostęp dziś. Na tej 
podstawie powstały dwa podobne do siebie trendy żywieniowe będące także stylami życia - less waste (mniej odpadów) oraz zero waste (zero odpadów). Główne cele tych trendów są takie same - każdy człowiek powinien żyć tak, aby nie generować odpadów, by zostawić Ziemię w tak dobrym stanie, w jakim ją zastano. Różnica między nimi polega na tym, iż propagatorzy less waste, zdając sobie sprawę, że redukcja odpadów do zera nie jest możliwa, starają się tę ilość jak najbardziej redukować. Zwolennicy zero waste natomiast uważają, że postawienie sobie tak trudnego do osiagnięcia celu, jakim jest całkowite niewytwarzanie odpadów, jest motywatorem ich działania, ponieważ „bezodpadowe życie” stanowi dla nich życiowe przedsięwzięcie.

Propagatorka idei zero waste Bea Johnson sformułowała 5R, czyli pięć zasad, które stały się kręgosłupem globalnego trendu żywieniowego zero waste - powinien się nimi kierować każdy człowiek chcący zredukować ilość produkowanych śmieci. $\mathrm{W}$ myśl tych pięciu zasad osoba żyjąca zgodnie $\mathrm{z}$ trendem zero waste powinna: odmawiać (refuse), ograniczać (reduce), używać ponownie (reuse), segregować i przetwarzać (recycle) oraz kompostować (rot) (Wagrowska, 2019).

Freeganizm jest trendem związanym z ekologiczną konsumpcją. Opiera się on na oszczędzaniu, racjonalnych zakupach i minimalizacji zużycia produktów. Freegańska filozofia „etycznego jedzenia” utrzymuje, iż kapitalizm i masowa produkcja opierają się na wyzysku pracowników, zwierząt i środowiska. Dlatego freeganizm jest postrzegany jako antykonsumpcyjny styl życia, który ogranicza udział w gospodarce i obejmuje zarówno poszukiwanie żywności w pojemnikach na śmieci, jak i prośby o zbędne lub niepotrzebne produkty, zanim zostaną one odrzucone przez sprzedawców na lokalnych rynkach, w restauracjach lub dużych sieciach handlowych (Zalega, 2015).

\section{Podsumowanie}

Konsumenci kierują się wieloma przesłankami w podążaniu za wybranymi trendami w żywieniu i nie są to wyłącznie czynniki zdrowotne (np. zapobieganie chorobom), alergie i nietolerancje pokarmowe, a także moda na dany sposób odżywiania, kwestie dbania o środowisko naturalne czy chęć utraty masy ciała.

Warto zauważyć, że nie tylko konsumenci powinni zwracać uwagę na występowanie pewnych trendów w żywieniu, powinni to czynić również m.in. producenci żywności, którzy muszą je znać i kreować, by być konkurencyjni w swojej branży.

Istotną kwestia jest odpowiednie podejście do przestrzegania zasad obowiązujących w trendach żywieniowych. Ważne jest rozsądne stosowanie każdej diety i jej odpowiednie zbilansowanie, konsultowanie jej z dietetykiem i lekarzem, a także zwracanie uwagi na to, czy nie znajdujemy się w grupie, dla której ta dieta jest niewskazana (np. weganizm a kobiety w ciąży), ponieważ wyłącznie wtedy można mieć pewność, że stosowanie diety nie będzie wpływać negatywnie na zdrowie. 


\section{Literatura}

ABCzdrowie.pl. (b.d.). Pobrano 28 grudnia z https://zywienie.abczdrowie.pl/produkty-o-wysokim-indeksie-glikemicznym

Adamiak, D. (2020). Insulinoodporność - dieta i charakterystyczne objawy. Pobrano 28 grudnia 2020 z https://bonavita.pl/insulinoodpornosc-dieta-i-charakterystyczne-objawy

Albala, K. (2015). The SAGE encyclopedia of food issues. Los Angeles: SAGE Publications.

Bartholomew, R. i Pearson, M. (2015). Mindful eating: Stop mindless eating and learn to nourish body and soul. New York: Ryland Peters \& Small.

Barton, L. (2018). Food mood boosters: 10 foods for mood improvement. Healthy Place. Pobrano 28 grudnia $2020 \mathrm{z}$ https:/www.healthyplace.com/self-help/food-mental-health/food-mood-boosters-10-foods-mood-improvement

Bizzozero, J. (2019). The importance of understanding the difference between a food trend or fad. Pobrano 28 grudnia $2020 \mathrm{zhttps}$ ://www.naturalproductsinsider.com/foods/importance-understandingdifference-between-food-trend-or-fad

Bonavita.pl. (b.d.). Pobrano 28 grudnia 2020 z https://bonavita.pl/dieta-o-niskim-indeksieglikemicznym-efekty-jadlospis-przepisy

Bubis, E. i Przetaczek-Rożnowska, I. (2016). Gluten i choroby wynikające z jego nietolerancji. KOSMOS. Problemy Nauk Biologicznych, 65(2), 293-294.

Bylok, F. (2018). Społeczne aspekty konsumpcji żywności - socjologiczna perspektywa. Handel Wewnętrzny, 1(372), 5-16.

Cambridge English dictionary. (2020). Cambridge University Press. Pobrano 28 grudnia $2020 \mathrm{z} \mathrm{https://}$ dictionary.cambridge.org/pl/dictionary/english/trend

Dejnaka, A. (2019). Sposoby odżywiania sie przez konsumentów - nowe trendy. W: W. Nowak \& K. Szalonka, (red.), Zdrowie i style życia. Wyzwania ekonomiczne i społeczne. Wrocław: E-Wydawnictwo. Prawnicza i Ekonomiczna Biblioteka Cyfrowa. Wydział Prawa, Administracji i Ekonomii Uniwersytetu Wrocławskiego.

Derbyshire, E. J. (2017). Flexitarian diets and health: A review of the evidence-based literature. Frontiers of Nutrition, 3(55), 1-8.

Desmond, M. i Sobiecki, J. (2019). Suplementacja w dietach wegetariańskich i wegańskich - praktyczne wskazówki. Pobrano 28 grudnia $2020 \mathrm{z}$ https://www.mp.pl/pacjent/dieta/zasady/220226,suplementacja-w-dietach-wegetarianskich-i-weganskich-praktyczne-wskazowki

Dittfeld, A., Gwizdek, K., Parol, D. i Michalski, M. (2018). Dieta bezglutenowa - charakterystyka grup docelowych. Postępy Higieny i Medycyny Doświadczalnej, (72), 227-239.

Domański, H., Karpiński, Z., Przybysz, D. i Straczuk, J. (2015). Wzory jedzenia a struktura społeczna. Warszawa: Wydawnictwo Naukowe Scholar.

Drabik, L. i Sobol, E. (2019). Stownik języka polskiego PWN. Warszawa: Wydawnictwo Naukowe PWN.

Fleksitarianizm. (b.d.). Pobrano 28 grudnia $2020 \mathrm{z}$ https://pl.wikipedia.org/wiki/Fleksitarianizm

Frączek, B., Krzywański, J. i Krysztofiak, H. (red.). (2019). Dietetyka sportowa. Warszawa: Wydawnictwo Lekarskie PZWL.

Gajda-Konopka, M. i Lesiów, T. (2017). Ocena wiedzy i nawyków żywieniowych u osób aktywnych fizycznie. Nauki Inżynierskie i Technologie, 2(25), 9-19.

Gawęcki, J. (2007). Wegetarianizm jako dieta alternatywna. W: T. Mossor-Pietraszewska \& J. Gawęcki (red.), Kompendium wiedzy o żywności, żywieniu i zdrowiu. Warszawa: Wydawnictwo Naukowe PWN.

Gertig, H. i Przysławski, J. (2006). Bromatologia. Zarys nauki o żywności i żywieniu, Warszawa: Wydawnictwo Lekarskie PZWL.

Górska, J. (2017). Produkty bezlaktozowe: Wzrost bez laktozy. Forum Mleczarskie Handel, 84(5). Pobrano 28 grudnia $2020 \mathrm{z}$ https://www.forummleczarskie.pl/RAPORTY/665/produkty-bezlaktozowe 
Grzybowska-Brzezińska, M. (2011). Świadomość ekologiczna konsumentów a ich zachowania na rynku żywności. Studia i Materiały Polskiego Stowarzyszenia Zarzadzania Wiedzq, (51), 242-253.

Gzyra, D. (2013). Krótka historia weganizmu. Fabularie, 2(2), 46-51.

Hanus, G. (2017). Prozdrowotne zachowania konsumentów na światowym rynku żywieniowym. Studia Ekonomiczne. Zeszyty Naukowe Uniwersytetu Ekonomicznego w Katowicach, (326), 75-88.

Hatalska, N. i Trapp, A. (2017). Future of food. Gdańsk: Infuture Hatalska Foresight Institute. Pobrano 28 grudnia $2020 \mathrm{zhttps} / /$ hatalska.com/wp-content/uploads/2017/07/Raport_Future_Of_Food_2017. pdf

Hirschmann, J. R. i Zaphiropoulos, L. (2012). Kids, carrots, and candy: A practical, positive approach to raising children free of food and weight problems. New York: CreateSpace Independent Publishing Platform.

Jankojć, A., Lesiów, T. i Biazik, E. (2016a), Substytuty mięsa firmy Quorn ${ }^{\mathrm{TM}}$ na polskim rynku. Część 1. Nauki Inżynierskie i Technologie, 3(22), 36-50.

Jankojć, A., Lesiów, T. i Biazik, E. (2016b), Substytuty mięsa firmy QUORNTM na polskim rynku. Część 2. Nauki Inżynierskie i Technologie, 4(23), 58-76.

Jaworski, M. i Fabisiak, A. (2017). Psychospołeczne determinanty wyboru żywności. Zeszyty Naukowe Uczelni Vistula, 54(3), 17-29.

Jedlecka, W. (2016). Wegetarianizm we współczesnych religiach światowych. Zarys problemu. Filozofia Publiczna i Edukacja Demokratyczna, 5(1), 263-278.

Kaczmarczyk, S. (2014). Badania marketingowe. Podstawy metodyczne. Warszawa: Polskie Wydawnictwo Ekonomiczne.

Kucner, A., Sierocki, R. i Wasyluk, P. (2018). Trendy. Interpretacje i konfrontacje. Olsztyn: Instytut Filozofii UWM w Olsztynie.

Kunachowicz, H., Czarnowska-Misztal, E. i Turlejska H. (2000). Zasady żywienia człowieka. Warszawa: Wydawnictwa Szkolne i Pedagogiczne Spółka Akcyjna.

Lofgren, I. (2015). Mindful eating? An emerging approach for healthy weight management. American Journal of Lifestyle Medicine, 9(3), 212-216.

Maj, A. (2018). Zmiana tendencji żywieniowych jako przykład zmiany społecznej. Transformacje, 1-2(96/97), 237-252.

Mennell, S., Murcott, A. i van Otterloo, A. H. (1992). The sociology of food: Eating, diet and culture. London: Sage.

Michałowska, J., Pastusiak, K. i Bogdański, P. (2017). Kontrowersje wokół glutenu. Wybrane Problemy Kliniczne, 8(3), 103-111.

Mindfull.com. (b.d.). Pobrano 28 grudnia 2020 z http://mindful.com.pl/artykuly/mindful-eating-czyli-uwazne-jedzenie

Nosarzewski, K. (2020). Producenci żywności wciqż korzystajq na rosnqcej zamożności polskiego konsumenta $i$ wzroście eksportu. Musza jednak wyprzedzać trendy żywieniowe. Pobrano 28 grudnia $2020 \mathrm{z}$ https://biznes.newseria.pl/news/producenci-zywnosci,p1841824160

Poulain, J. P. (2002). Sociologies de l'alimentation. Paris: Presses Universitaires de France.

Pyrzyńska, E. (2013). Dieta wegetariańska w świetle zasad prawidłowego odżywiania - postawy i zachowania wegetarian w Polsce. Zeszyty Naukowe Uniwersytetu Ekonomicznego w Krakowie, (906), 27-36.

Radziszewska, A. (2017). Nowe wzorce konsumpcji w zachowaniach polskich konsumentów. Handel Wewnętrzny, 1(366), 286-297.

Różańska, M. (2020). Dieta w insulinooporności. Pobrano 28 grudnia 2020 z https://www.hellozdrowie.pl/artykul-dieta-w-insulinoopornosci

Stanowisko Komitetu Nauki o Żywieniu Człowieka PAN w sprawie wartości odżywczej i bezpieczeństwa stosowania diet wegetariańskich. (2019). Pobrano 28 grudnia $2020 \mathrm{z}$ http://www.knozc.pan. pl/images/stories/MLonnie/Stanowisko_KNoZc_WEGETARIANIZM_do_glosowania.pdf 
Stolińska-Fiedorowicz, H. (2017). Wegetarianizm - za i przeciw. Narodowe Centrum Edukacji Żywieniowej Instytutu Żywności i Żywienia. Pobrano 5 maja 2020 z https://ncez.pl/nauka-zrozumialadla-ciebie---wywiady-z-ekspertami/diety-wegetarianskie

Wansink, B. (2010). From mindless eating to mindlessly eating better. Physiology \& Behavior, (100), 454-463.

Wansink, B. i Sangerman, C. (2000). Engineering comfort foods. American Demographic, 66-67.

Wagrowska, K. (2019). Życie zero waste. Warszawa: Społeczny Instytut Wydawniczy Znak.

Wieczorek, K. M. (2016). Czy miłośnik i obrońca zwierzat może zjadać swoich przyjaciół? Wegetarianizm i wspótczucie w myśli Artura Schopenhauera. W: Ludzkie, nie-ludzkie, arcyzwierzęce. Animalocentryzm? Siemianowice Śląskie: Wydawnictwo Leimak.

Wieczorkiewicz, R. (2018). Naukowcy przestrzegaja, że produkty bez laktozy mogq zaszkodzić. Pobrano 28 grudnia $2020 \mathrm{z}$ https://www.portalspozywczy.pl/mleko/wiadomosci/naukowcyprzestrzegaja-ze-produkty-bez-laktozy-moga-zaszkodzic, 155058_1.html

Wiśniewska, K. (2018). Dieta fleksitariańska, czyli... elastyczny wegetarianizm. Pobrano 28 grudnia 2020 z https://ncez.pl/abc-zywienia-/zasady-zdrowego-zywienia/dieta-fleksitarianska--czyli---elastyczny-wegetarianizm

Włodarek, D., Lange, E., Kozłowska, L. i Głąbska, D. (2014). Dietoterapia. Warszawa: Wydawnictwo Lekarskie PZWL.

Zalega, T. (2015). New Consumer Trends. W: Burchard-Dziubińska, M. (red.). Towards a Green Economy. From ideas to practice. Łódź: Wydawnictwo Uniwersytetu Łódzkiego.

Żakowska-Biemans, S. (2011). Aspekty etyczne w zachowaniach konsumentów na rynku żywności ekologicznej. Studia i Materiały Polskiego Stowarzyszenia Zarzadzania Wiedzq, 52, 76-84. 